\title{
Interpretation Awareness of Creativity Mathematics Teacher High School
}

\author{
Ajeng Gelora Mastuti ${ }^{1,2}$, Toto Nusantara ${ }^{3}$, Purwanto $^{3}$, Abdurrahman As' ari $^{3}$, Subanji $^{3}$, Abadyo $^{3} \&$ Susiswo $^{3}$ \\ ${ }^{1}$ S3 Departement of Mathematic Education, Graduate Universitas Negeri Malang, Indonesia \\ ${ }^{2}$ IAIN Ambon, Indonesia \\ ${ }^{3}$ Faculty of Mathematics and Natural Sciences, Department of Mathematics Education, Universitas Negeri \\ Malang, Indonesia
}

Correspondence: Ajeng Gelora Mastuti, S3 Departement of Mathematic Education, Graduate Universitas Negeri Malang, IAIN Ambon, Indonesia. E-mail: ajengabdillah65@gmail.com

\author{
Received: December 17, $2015 \quad$ Accepted: March 1, $2016 \quad$ Online Published: August 25, 2016 \\ doi:10.5539/ies.v9n9p32 \\ URL: http://dx.doi.org/10.5539/ies.v9n9p32
}

\begin{abstract}
The purpose of this study are: a) to investigate high school math teacher creativity equality, b) to investigate what factors can inhibit their creativity consciousness. The subjects of this study consisted of two high school math teacher who had a different experience academically. The results of the qualitative research show the relationship between creativity and high school math teacher is focused on procedures and not on the product, presents the conception refers to the creativity in the perspective of learners. The observation of classes conducted by researchers for two weeks in a row can be used as an indicator that in teaching mathematics, high school teacher who observed indirectly applying creativity in teaching math though their confidence is lacking. They give an opportunity to him to be a creative individual and attractive in front of their students and provide opportunities to students to construct their own concepts and develop logical arguments. Overall a high school math teacher is still not directly aware of his creativity, but they can improve the confidence of the students. Based on the result of reflection and interviews obtained factors that can inhibit the creativity of teachers, among others; lack of confidence of teachers to students, the limited time to realize the ability of students, teachers internal and external activities that take a lot of time learning. Factors that could hinder the creativity of teachers compiled by researchers through depth interviews with high school teachers.
\end{abstract}

Keywords: creativity awareness, high school math teacher

\section{Introduction}

\subsection{Introduce the Problem}

Creativity is an integral part of mathematics (Brunkalla, 2009) and has been proposed as one of the major components to be included in mathematics education, since "the essence of mathematics is thinking creatively" (Mann, 2006). A review of the literature about creativity in general and mathematical creativity in particular reveals different definitions (Leikin et al., 2013) and various approaches and interpretations (Shriki, 2010). Creativity in mathematics may be characterized in several ways such as employing non-algorithmic decision making as well as divergent and flexible thinking which allows one to pursue many different avenues and perspectives in solving a problem (Levenson, 2013). Some researchers refer to creativity using expressions that relate to cognitive abilities such as aptitude, approach, and knowledge (Sternberg \& Lubart, 1996), or to conceptual thinking abilities that involve flexibility, fluency, and originality (Leikin \& Pitta-Pantazi, 2013). Sriraman (2004) argues that in the context of mathematics, "it is sufficient to define creativity as the ability to produce novel or original work". As Livne and Milgram (2006) claim, creative ability in mathematical thinking is the ability to perceive patterns and relationships using complex and non-algorithmic thinking, and being capable of original thinking in mathematical symbols.

Creativity is a vital avenue of study in educational research. It is one of the most highly regarded cognitive traits within the fields of psychology and education, and for good reason. The ability to think creatively has a long list of benefits, including social, intellectual, educational, emotional and talent-based achievement in school and in life (Guilford, 1950; Renzulli, 1994; Torrance, 1970; Blicbau \& Steiner, 1998). In schools, promoting creative 
thinking helps students to discover and pursue their intellectual interests, as it tends to increase student engagement with ideas and learning, therefore maximizing success in learning (Amabile, 1989). Torrance (1981) found that improved concentration, curiosity, motivation, and achievement were seen in instances where creative learning occurred. And "thus, creative teaching can enhance learning" (Fasko, 2000-2001). Teachers who inspire creativity in their students have been found to model creative or divergent thinking themselves (Karnes et al., 1961). Educational researchers have noted that creative teachers advance students' learning experiences, and heighten their potential and engagement (Renzulli, 1992; Hickey, 2001; Cropley, 2003; Fasko, 2001; Lilly \& Bramwell-Rejskind, 2004).

Creativity is an essential factor in thinking and learning which cuts across all disciplines. There is a general conviction that creativity should be supported and developed educational settings (Williams, 2002). However there remains little understanding of effective applications of creative teaching in classroom teachers. This may be due to the complex nature of creativity, and the lack of a consistent definition of "what creativity is" or "what it means" in teaching or educational research (Marksberry, 1963; Sternberg, 1999; Baker et al., 2001; Friedel \& Rudd, 2005).

Based on this, the curriculum reform has done and creativity included in education policy in western countries, like the United States, Britain, France, Germany, Sweden, and Auatralia (Craft, 2005; Feldman \& Benjamin, 2006; Shahen 2010). Asian countries are also responding to this trend. For example, insistence education reform to produce children's creative potential in China, due to the phenomenon of students who are high achievers in mathematics in the international arena has recorded low ratings in the imagination and creativity (Jun, Wu, \& Al-banese, 2010). In Hong Kong, creativity recognized as one of the three generic skills be developed in education, and some general principles to develop creativity included in the curriculum (Cheng, 2010). In other countries such as Japan, South Korea, Taiwan, and Singapore have also been reformed curriculum with an emphasis on developing of creativity (Choe, 2006; Shahen, 2010).

\subsection{Explore Importance of the Problem}

In addition, teachers' attitudes and beliefs may also be an issue. Though most teachers claim that they value creativity (Runco \& Johnson, 2002), their implicit attitudes indicate negativity towards creative students (Runco \& Johnson, 1993; Westby \& Dawson, 1995). In Westby and Dawson's (1995) study, teachers' least favorite students showed more characteristics that were identified by experts as creative, than teachers' favorite students did. In fact, this study showed that teachers interpreted creativity differently from expert definitions. Though experts identified characteristics such as nonconformity, emotionality, impulsivity, and trying to do what others think was impossible as typical creative traits, teachers rated them as the least creative traits (Westby \& Dawson, 1995). Similarly, teachers in Scott's (1999) study also showed negative attitudes towards creative students. Those teachers perceived creative students as disruptive (Scott, 1999). Even among prospective teachers, it was found that these teachers had already developed an opinion that students' unique and novel responses in classroom discussions were potential distractions (Beghetto, 2007). Moreover, compared to teachers teaching other subjects, the negative attitude towards creativity was even stronger among teachers teaching mathematics (Beghetto, 2007).

Researchers conducted observations of a math teacher who taught in Mojokerto and a high school teacher who taught in Jombang. Both teachers are so favored by students, it is visible when the teacher enters the classroom students are so enthusiastic and excited. Both teachers have the same education, the master of mathematics education. One teacher observed by researchers in Jombang an outstanding teacher two years in a row and is now a national instructor. The first teacher to teach students to use various ways and quick tricks in teaching mathematics, the teacher prefers long process and a detailed explanation of the students. Both the teacher explained to the researchers that even more skills and good language and light are the main requirements that should hold by teachers so that students are able to think creatively. But sometimes both the teacher explained to the researchers that they often neglect students of different explanations with him, and they realized that lack of confidence towards the new students realized after completion of learning. So researchers interested to probe deeper awareness of these teachers on their creativity in teaching mathematics and their ability to recognize students who think creatively.

\subsection{Describe Relevant Scholarship}

The results of the research so far show that teachers tend to encourage creativity merely in theory anyway, the teacher does not feel responsible for the creativity of teaching (Aljughaiman \& Mowrer-Reynolds, 2005) and may find creative solutions to solving problems that disrupt (Beghetto, 2007). Teachers rarely taught to show their creativity, but teachers who are productive are teachers who have more creativity (Schacter, Thum, \& 
Zifkin, 2006).

Normandia and Greer (2005) find a mathematics teacher, even though the majority of students have participated in presenting their work to resolve the issue and write it on the board before class began, none of them ever asked to explain how and why they solve the problem as they write or do. In other words, none of them ever asked to take part in discussions about their work before the math teacher explained. In a lot of math class, there is a great emphasis placed on reading and listening skills, to leave verbal and written communication skills (Wood, 2012). In addition, according to Wood, is often assumed that in learning mathematics students will automatically capture and "absorb" the discourse used by the teacher to explain the material, it is considered the teacher had been able to communicate mathematical ideas being studied. Maybe this is not a problem for many students, but for teaching mathematics using only the discourse will have a negative impact on many students (Baber, 2011). Math is taught using the language, teachers assess students' understanding through the language they use, and students understand the ideas they use language (Wium \& Louw, 2012). Huang and Normandia (2009) revealed their research, that language becomes essential for the student's ability to process and understand the mathematics. In fact, research Huang and Normandia (2009) indicates that the communication was a major factor in the learning of mathematics. It shows that the idea of communication is very important in the learning done by a teacher in the classroom. Panaoura (2014) investigated the awareness of student teachers in mathematical creativity and especially their ability to transfer knowledge to pedagogical mathematical creativity into lesson plans and advise them in practice indications.

Previous studies that have been described above indicates that teacher beliefs about herself and her students are still lacking, so teachers need to be aware of its creativity in teaching mathematics.

\subsection{State Hypotheses and Their Correspondence to Research Design}

Researchers identify awareness of the creativity of teachers through two, namely the scope of the creativity of teachers viewed during classes, as well as the attitudes and beliefs of teachers to student responses. The indicator is used as the initial observation data in a knowing awareness of mathematical creativity of teachers in the classroom teaching.

Researchers explain the factors inhibiting creativity awareness of teachers through observation and interviews. Teachers realize that there are factors that inhibit creativity during teaching.

Teachers must be fluent in lesson management, flexible in reacting to students' unexpected responses, and original in using surprising teaching ideas. This study concentrates on final result primarily from creativity of mathematics teachers in the classroom and the teacher's knowledge of the creativity students. The purposes of this study are: a) to investigate the awareness of creativity of high school math teacher; and b) to investigate what factors could inhibit their creativity consciousness. Researchers believe that if teachers understand their ability to show and propose creative activities for teaching mathematics and have a better attitude and a positive belief in the ability their students, the teacher will have a greater awareness of the creativity.

\section{Method}

The study was based on the constructivist paradigm (also known as the paradigm interpretation). A constructivist view of the world where researchers spent a lot of time in the field, notified to some people's views, and try their best to understand and present in detail (Creswell, 2013). This research was conducted in the first semester of 2015. To explore the knowledge "creativity" of high school teachers in mathematics affecting its awareness of its mathematical creativity and the factors that inhibit awareness of mathematical creativity.

The knowledge of mathematical creativity high school teachers was known by researchers through direct observation in the classroom during two lessons. Researchers saw teachers comprehension, interacting and exchanging information with teachers, conducted in-depth conversation, and details gathered to express comprehension of the creative math teacher for teaching and to know what factors inhibit mathematical awareness creativity.

\subsection{Identify Subsections}

1) Observing 10 mathematics teachers from three different schools, among others: SMAN 1 Bangsal Mojokerto, SMAN 3 Jombang, and SMA 1 Hangtuah Surabaya.

2) Choose two teachers who meet the specified criteria researchers. The teachers come from SMAN 1 Bangsal Mojokerto and SMAN 3 Jombang.

3) Analyze teachers through observation that meet the following criteria: a) have the ability to express ideas well which include: the notion put forward a rational, systematic forward ideas, logical thinking clearly, in a 
language easily understood, the reasons put forward according to the rules of mathematics. These criteria can be seen when teachers teach, lead discussions, give opinions, or asked, b) has the ability to write with good mathematical problem solving, including: completion of clear steps, each step proposed obvious reasons, the relationship every step clearly completion. These criteria can be seen from the writings of teachers in the board as explained, or power point that has been prepared teachers.

4) Interviewing teachers to describe awareness of creativity and the factors that inhibit creativity during class.

\subsection{Participant (Subject) Characteristics}

The subjects consisted of two high school math teachers. During five weeks, researchers met directly with the subjects, 2 weeks were used for direct observation in the classroom, to measure comprehension of mathematical creativity of high school teachers for teaching, researchers measured using observation sheet. In the third week, the researcher exchanged the information with the subject and conducted the in-depth conversation about the response of teachers to his awareness during teaching and understanding of the students creativity. In the last week, the researchers analyzed the findings in the class and exchanged ideas with the subject through direct conversations about researcher's findings related to the factors that inhibited the creativity of mathematics teachers in the classroom.

\subsection{Research Instruments}

One effort that could be used as the basis to realize creativity of high school math teacher is the belief in himself in teaching, it can see from the number of positive responses from students and great confidence in the ability possessed by students. Often the teacher gives examples of questions that can dig up the process of creative thinking of students is also a reference to see how big the belief of teachers to students that can affect the consciousness of the creativity possessed. Examples of questions used in observational studies teacher who is assumed to be able to explore the thinking of students and teachers to explore awareness of creativity itself.

Is the following system of linear equations having solutions? Explain your answer.

$$
\begin{aligned}
& 2 x-5 y=8 \\
& 3 x-6 y=a
\end{aligned}
$$

\subsection{Data Analysis}

Data analysis process starting before researchers entering the field. The data analysis continue as investigators were on the field at the time of completing the task of researchers in the field. Before researchers entering the field, is a data analysis conducted the preliminary study. Analysis of this data is directed to determine the focus of research in the form of awareness of the creativity of teachers in the teaching of mathematics and the factors that can hinder creativity of teachers in the classroom.

\section{Findings and Discussion}

Most teachers defined creativity refers to the authenticity of the final product. The data analysis research on the relationship between creativity and high school math teacher focused on procedures and not on the product, presented the conception refers to the creativity in the perspective of learners. For example, creativity in mathematics is not associated with the final result, but the process presented by the students to get the appropriate results. During troubleshooting procedures "the students explore the different ideas to find a solution". Teacher showed his perspective about creativity, and during the teaching process, the teachers tried to promote mathematical creativity. Teachers believed, if the students was faced with the new problem-solving for them, then the student was indirectly trying to use the element of originality or novelty to deal with the new situation. The creativity of students could affect the mathematical environment given to them (Baran et al., 2011).

Researchers did not only observe high school teacher giving the problem of the system of linear equations of two variables, but also notice a previous picture made by the teachers about the problems that they will give to the students. In the design of the picture, teachers began to write alternative process to answer questions devised by students. In the practice of the four processes answers described by teachers, students had answered three of the four answers and given reasons respectively. A student found it difficult to write the answer, but he was able to give good reason to the teacher. 


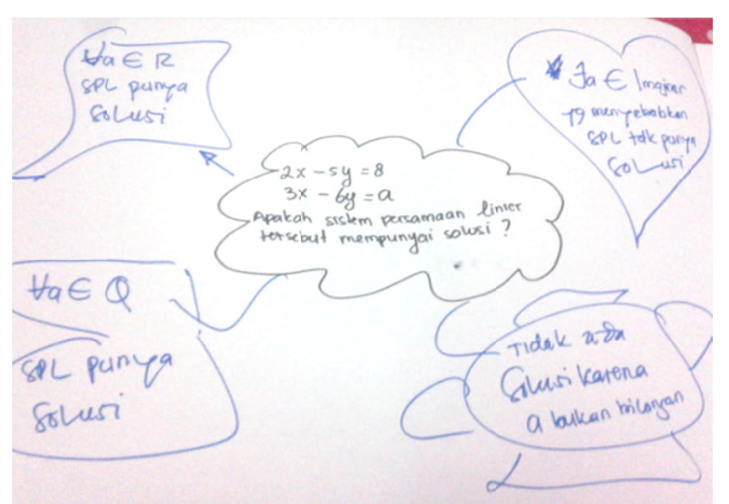

Picture 1. A teacher's illustration to the students' alternative answer

One possible student answer thought by the teacher was described with the words "there is no solution, because "a" is not number". In the classroom practice, more than $50 \%$ of students said that the problems given by the teacher did not have a solution to a variety of reasons, a student said because "a" was not a number, because the universe was not clear, and because of the unknown value of "a". The students' reasons in the class were based on the assumption that most students responded with a verbal way.

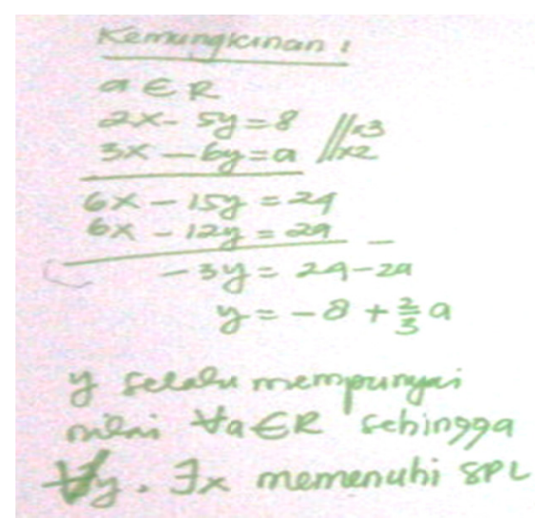

Picture 2. The teacher's illustration of the first student's possible answers

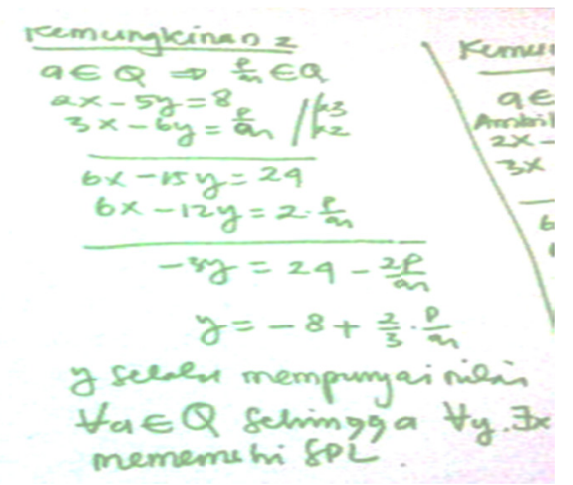

Picture 3. The teacher's illustration of the second student's possible answers

The other students tried to presuppose that $\forall \mathrm{a} \in \mathrm{R}$ and $\forall \mathrm{a} \in \mathrm{Q}$. In fact less than $30 \%$ of students in the class replied by presupposing $\forall \mathrm{a} \in \mathrm{R}$ and $\forall \mathrm{a} \in \mathrm{Q}$. It was based on the average students's work on using substitution and elimination. 


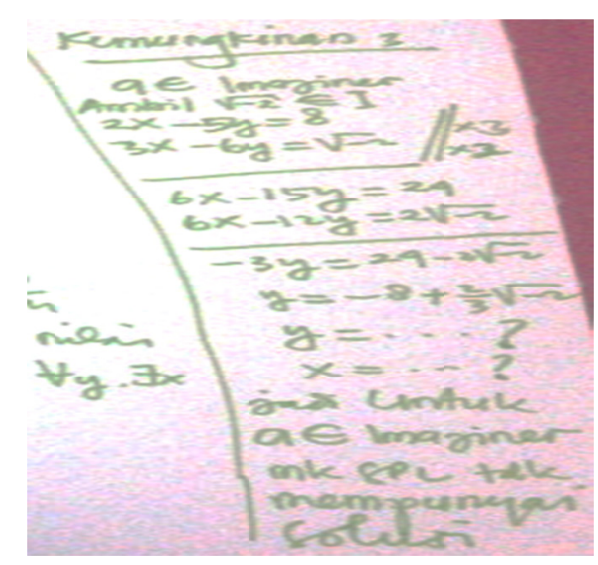

Picture 4. The teacher's illustration of the third student's possible answers

The third answer's draft described by teachers was a possibility if students presupposed that $\forall \mathrm{a} \in$ was imaginary. In fact there was no student thought that "a" was element of the imaginary. During the students thinking about solving the problems made by the teachers, the researchers had conversations with teachers about the habits experienced by teachers during teaching mathematics in the classroom. The teacher explained that she often used to use different instructional design depended on the materials presented, trying to understand the students learning styles using different methods, such as visual aids, video or other multimedia, realizing that every student had a different prior knowledge and therefore it contributed to the process of creative thinking.

Snatches of conversation between researchers and teachers while waiting for students to come to the board expressing his argument:

Researchers : Are you sure that there is students who will answer as your previous allegation?

Teacher : yes, maybe not all students answer as I have described, or there is students who will answer beyond my expectations.

Researcher : Which student is classified as students who do the creative thinking process?

Teacher : all students giving a rational reason certainly have thought creatively, but the students who had a logical and new answer certainly are the creative students.

Researcher : Do you always observe your students in advance? for example the process of creative thinking.

Teacher : Yes, students who think critically and creatively will be guided further to be able to articipate at the National Olympiad.

Snatches of conversation between researchers with teachers indicated that teachers choosen as the subject understood to the creativity of their students. Observations and interviews with teachers also explained that teachers had an awareness of their own creativity, although they realized that there were several factors that could inhibit creativity or make negligent towards their creativity.

We considered creativity as the dynamic characteristics that could be developed during the educational process and we strongly believed that the value of creativity in mathematics should not be underestimated (Chamberlin \& Moon, 2005). This research was motivated by the belief that teachers should be responsible for developing a supportive and beneficial environment for the creative ideas and the teachers'ability to propose teaching activities in order to develop their creativity.

Some researches revealed that math teachers was not creative in applying mathematical concepts and assume that it was difficult to develop a mathematical creativity. These findings were supported by Bolden et al. (2010), when all teachers were interviewed, they did not see mathematics as a creative subject. It was important for teachers to be aware of their difficulties and limitations in the application of their knowledge about pedagogy theory, because it was the first step for teachers to develop their creativity and overcome the obstacles that existed so far. This study had many limitations in terms of subject and procedures that had been used. We had to remember that the subjects had an additional personal interest to mathematics education. It would be interesting to continue our research by observing certain participants next year, especially for teachers who recently had their first teaching mathematics experience in high school. We were sure that the awareness of math teacher would provide a good contribution to our research further and for the involved school in order to increase more 
the student's confidence and develop the creativity for education.

\section{Results and Implications}

The result of reflections and interviews with teachers 1 and teacher 2 , then the results were as follows: teachers 1 did not directly provide the problems of creative thinking in students, but it was preceded by much simpler questions in advance, the learning time was 20 minutes longer than usual, students took nearly 45 minutes to think about the answers to the problems set by the teacher, some still often asked their friends, teachers knew well to assess students from the aspect of novelty and flexibility, sometimes teachers often provided intervention to the students' verbal reason, because they were busy on other students' activities sometimes teachers did not respond to the students' question who wanted to know why the other students' answers did not the same as him, sometimes teachers left the classroom when students were working on the problem because of an internal activity at school; While teachers 2 tends to immediately gave open-ended problems or problems that allow students to think creatively, teachers always gave a time limit for the work of students, teachers less tolerated the students' answers which were not in accordance with himself, learning time was 5 minutes longer, the teachers appreciated the different students' argument but they responded less the various students' question because it was out of the problem given, quite understood in assessing the creativity of students, teachers sometimes received phone in class because of external events which they would participate. Based on the result of reflection and interview, then the researcher obtained the factors that could inhibit the creativity of teachers, among others; lack of confidence of teachers to different students'argument, the limited time to realize the ability of students, teachers internal and external activities which took a lot of time learning. Factors that might inhibit creativity of teachers summarized by researchers through depth interviews with high school teachers.

The classroom observation result conducted by researchers for two weeks sequently can be used as an indicator that in teaching mathematics, high school teacher who observed indirectly had applied creativity in teaching mathematics even though they were sorely lacking confidence. They provided opportunities for him to become a personal creative and attractive in front of different students'argument, and for students to construct their own concepts and develop logical arguments. Overall high school math teachers were not directly aware of his creativity, but they could improve the confidence to the students. In this study, high school teachers have been able to distinguish the ability of different students'argument based on prior knowledge and learning style, able to attract the attention, able to accept the students'argument in The classroom, able to know their abilities and able to predict the different students'argument response,and able to indirectly define the creativity in teaching mathematics.

Researchers believe that this study can directly contribute to further research to develop the ability of teachers to interpret awareness of creativity and promote creativity in the classroom. The implications of this research are expected to contribute to the awareness of the theory of the creativity of teachers, improve their skills in learning innovation which leads to the growth of students' ability to think creatively, and increase awareness of teachers primarily through the creative assignment.

\section{Acknowledgments}

We thank Mr. Abdillah to share inspiring insights on these issues, Mr. Prayitno in SMAN 3 Jombang who assist in conducting research, and friends of the class B 2014 Mathematics Education doctoral program who took the time for discussion.

\section{References}

Aljughaiman, A., \& Mowrer-Reynolds, E. (2005). Teachers' conceptions of creativity and creative students. Journal of Creative Behavior, 39(1), 17-34. http://dx.doi.org/10.1002/j.2162-6057.2005.tb01247.x

Amabile, T. M. (1989). Growing up creative. Buffalo, NY: The Creative Education Foundation.

Baber, R. (2011). The Language of Mathematics: Utilizing Mathematics in Practice. New Jersey: John Wiley \& Sons, Inc. Retrieved from http://onlinelibrary.wiley.com/doi/10.1002/9781118061770.fmatter/pdf

Baker, M., Rudd, R., \& Pomeroy, C. (2001). Relationships between critical and creative thinking. Journal of Southern Agricultural Education, 51(1), 173-188. http://dx.doi.org/10.1.1.573.376

Baran, G., Erdogan, S., \& Cakmak, A. (2011). A Study on the Relationship between Six-Year-Old Children's Creativity and Mathematical Ability. International Education Studies, 4(1), 105-111. http://dx.doi.org/10.5539/ies.v4n1p105

Beghetto, R. A. (2007). Does creativity have a place in classroom discussions? Prospective teachers' response preferences. Thinking Skills and Creativity, 2(1), 1-9. http://dx.doi.org/10.1016/j.tsc.2006.09.002 
Blicblau, A. S., \& Steiner, J. M. (1998). Fostering creativity through engineering projects. European Journal of Engineering Education, 23(1), 55-65. http://dx.doi.org/10.1080/0304379980230107

Bolden, D., Harries, A., \& Newton, D. (2010). Pre-service primary teachers' conceptions of creativity in $\begin{array}{llll}\text { mathematics. Educational Studies in } & \text { Mathematics, } & \text { 73(2), }\end{array}$ http://dx.doi.org/10.1007/s10649-009-9207-z

Brunkalla, K. (2009). How to increase mathematical creativity - an experiment. The Montana Mathematics Enthusiast, 6(1), 257-266. http://scholarworks.umt.edu/tme/vol6/iss1/20

Chamberlin, S., \& Moon, S. (2005). Model-eliciting activities as a tool to develop and identify creatively gifted mathematicians. Journal of Secondary Gifted Education, XVII(1), 37-47. http://dx.doi.org/10.4219/jsge-2005-393

Cheng, V. M. Y. (2010). Tensions and Dilemmas of teachers creativity reform in a Chinese context. Thinking skills and creativity, 5, 120-137. http://dx.doi.org/10.1016/j.tsc.2010.09.005

Choe, I. S. (2006). Creativity-A sudden rising star in korea. In J. C. Kaufman, \& R. J. Sternberg (Eds), The International Handbook of creativity. New York, NY: Cambridge University Press. http://dx.doi.org/10.1017/CBO9780511818240.014

Craft, A. (2005). Creativity in school: tensions and dilemmas. London: Y.-S. Lin 154 Routledge. http://dx.doi.org/10.4324/9780203357965

Creswell, J. (2013). Qualitative inquiry and research design: Choosing among five approaches (3rd ed.). Thousand Oaks, CA: Sage.

Cropley, A. J. (2003). Creativity in education \& Learning. Bodmin, Cornwall: Routledge Falmer.

Fasko, D. J. (2000-2001). Education and creativity. Creativity Research Journal, 13(3\&4), 317-327. http://dx.doi.org/10.1207/S15326934CRJ1334_09

Feldman, D. H., \& Benjamin, A. C. (2006). Creativity and education: an American retrospective. Cambridge journal of education, 36, 319-336. http://dx.doi.org/10.1080/03057640600865819

Friedel, C., \& Rudd, R. (2005). Creative thinking and learning styles in undergraduate agriculture students. National AAAE Reserach Conference (pp. 199-211). http://dx.doi.org/10.5032/jae.2006.04102

Guilford, J. (1950). Creativity. American Psychologist, 444-454. http://dx.doi.org/10.1037/h0063487

Hickey, M. (2001). Creativity in the music classroom. Music Educators Journal, July, 17-18. http://dx.doi.org/10.2307/3399772

Huang, J., \& Normandia, B. (2009). Talking and Writing Math-A students' perspective in a secondary math class. The International Journal of Learning, 16(5), 1-21. Retrieved from http://www.Learning-Journal.com

Karnes, M. B., McCoy, G. F., Zehrbach, R. R., Wollersheim, J. P., Clarizio, H. F., Costin, L., \& Stanley, L. S. (1961). Factors associated with underachievement and overachievement of intellectually gifted children. Champaign, IL: Champaign Community Unit Schools.

Leikin, R., \& Pitta-Pantazi, P. (2013). Creativity and Mathematics Education: The state of art. ZDM Mathematics Education, 45, 159-165. http://dx.doi.org/10.1007/s11858-012-0459-1

Leikin, R., Subotnik, R., Pitta-Pantazi, D., Singer, F., \& Pelczer, I. (2013). Teachers' views on creativity in mathematics education and international survey, ZDM, Mathematics Education, 45, 309-324. http://dx.doi.org/10.1007/s11858-012-0472-4

Levenson, E. (2013). Tasks that may occasion mathematical creativity: Teachers' choices. Journal of Mathematics Teacher Education, 16, 269-291. http://dx.doi.org/10.1007/s10857-012-9229-9

Lilly, F. R., Bramwell-Rejskind, G. (2004). The dynamics of creative teaching. The Journal of Creative Behavior, 38(2), 102-124. http://dx.doi.org/10.1002/j.2162-6057.2004.tb01235.x

Livne, N., \& Milgram, R. (2006). Academic versus creative abilities in mathematics: Two components of the $\begin{array}{lllll}\text { same construct? } \quad \text { Creativity } & \text { Research }\end{array}$ http://dx.doi.org/10.1207/s15326934crj1802_6

Mann, E. (2006). Creativity: The essence of mathematics. Journal for the Education of the Gifted, 30(2), 236-260. http://dx.doi.org/10.4219/jeg-2006-264

Marksberry, M. L. (1963). Foundations of creativity. New York: Harper \& Row. 
Normandia, B., \& Greer, S. (2005). Communicating mathematically: Comparison of knowledge structures in teacher and student discourse in a secondary math classroom. Communication Education, 54(1), 34-51. http://dx.doi.org/10.1080/14613190500077002

Panaoura, G., \& Panaoura, A. (2014). Teachers' awareness of creativity in mathematical teaching and their practice. IUMPST. 4. Retrieved from http://www.k-12prep.math.ttu.edu

Renzulli, J. (1992). A general theory for the development of creative productivity through the pursuit of ideal acts of learning. Gifted Child Quarterly, 36, 170-182. http://dx.doi.org/10.1177/001698629203600402

Renzulli, J. S. (1994). Schools for talent development: A practical plan for total school improvement. Mansfield Center, CT: Creative Learning Press. http://dx.doi.org/10.1177/019263659507956820

Runco, M. A., \& Johnson, D. J. (1993). Parents' and teachers' implicit theories on children's creativity. Child Study Journal, 23(2), 91-109. http://dx.doi.org/10.1146/annurev.psych.55.090902.141502

Runco, M. A., \& Johnson, D. J. (2002). Parents' and teachers' implicit theories of children's creativity: A cross-cultural perspective. Creativity Research Journal, 14(3), 427-483. http://dx.doi.org/10.1207/S15326934CRJ1434_12

Schacter, J., Thum, Y. M., \& Zifkin, D. (2006). How much does creative teaching enhance elementary school $\begin{array}{llll}\text { students' achievement? Journal of Creative Behavior, 40(1), } & \text { 47-72. }\end{array}$ http://dx.doi.org/10.1002/j.2162-6057.2006.tb01266.x

Scott, C. (1999). Teachers' biases toward creative children. Creativity Research Journal, 12(4), 321-328. http://dx.doi.org/10.1207/s15326934crj1204_10

Shahen, R. (2010). Creativity and Education. Creative education, 1, 166-169. http://dx.doi.org/10.4236/ce.2010.13026

Shriki, A. (2010). Working like real mathematicians: developing prospective teachers' awareness of mathematical creativity through generating new concepts. Educational Studies in Mathematics, 73, 159-179. http://dx.doi.org/10.1007/s10649-009-9212-2

Sriraman, B. (2004). The characteristics of mathematical creativity. The Mathematics Educator, 14(1), 19-34. Retrieved from http://jwilson.coe.uga.edu/DEPT/TME/Issues/v14n1.sriraman.pdf

Sternberg, R. (1999). The Concept of Creativity: Prospect and Paradigms. In R. Sternberg (Ed.), Handbook of creativity (p. 137). New York: Cambridge University Press. http://dx.doi.org/10.1017/CBO9780511807916.003

Sternberg, R. J., \& Lubart, T. I. (1996). Investing in creativity. American Psychologist, 51(7), 677-688. http://dx.doi.org/10.1037/0003-066X.51.7.677

Torrance, E. (1981). Creative teaching makes a difference. In J. K. J. C. Gowan (Ed.), Creativity: Its educational implications (2nd ed., pp. 99-108). Dubuque, IA: Kendall/Hunt.

Torrance, E. P., \& Khatena, J. (1970). What kind of person are you? Gifted Child Quarterly, 14, 71-75. http://dx.doi.org/10.1177/001698627001400201

Westby, E. L., \& Dawson, V. L. (1995). Creativity: Asset or burden in the classroom? Creativity Research Journal, 8(1), 1-10. http://dx.doi.org/10.1207/s15326934crj0801_1

Williams, S. D. (2002). Self-esteem and the self-censorship of creative ideas. Personnel Review, 31(4), 495-503. http://dx.doi.org/10.1108/00483480210430391

Wium, A.-M., \& Louw, B. (2012). Continued Professional Development of Teachers to Facilitate Language Used in Numeracy and Mathematics. The South African Journal of Communication Disorders.

Wood, L. (2012). Practice and Conceptions: Communicating Mathematics in The Workplace. Educational Studies in Mathematics, 79(1), 109-125. http://dx.doi.org/10.1007/s10649-011-9340-3

Wu, J. J., \& Albanese, D. (2010). Asian creativity, chapter one: Creativity across three Chinese societies. Thinking Skills and Creativity, 5, 150-154. http://dx.doi.org/10.1016/j.tsc.2010.10.002 


\section{Copyrights}

Copyright for this article is retained by the author(s), with first publication rights granted to the journal.

This is an open-access article distributed under the terms and conditions of the Creative Commons Attribution license (http://creativecommons.org/licenses/by/4.0/). 